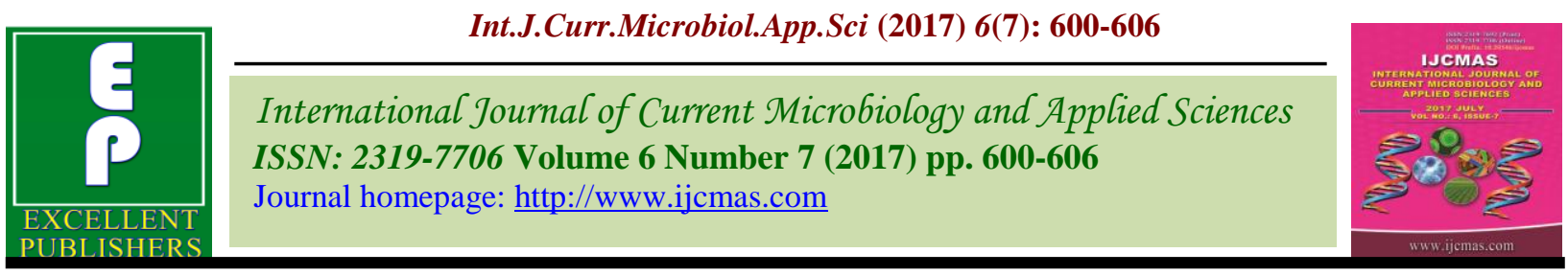

Original Research Article

https://doi.org/10.20546/ijcmas.2017.607.073

\title{
Influence of Nitrogen and Sulphur on Yield and Quality Parameters of Spineless Safflower under Irrigated Conditions
}

\author{
J.K. Revanth Nathan*, A. Madhavi Lata, B. Joseph and A. Madhavi \\ Department of Agronomy, College of Agriculture, Professor Jayashankar Telangana State \\ Agricultural University, Rajendranagar, Hyderabad-500 030, Telangana, India \\ *Corresponding author
}

\section{A B S T R A C T}

Keywords

Yield parameters, Quality, Nitrogen levels, Sulphur levels.

Article Info

Accepted:

14 June 2017

Available Online:

10 July 2017
A field experiment was conducted during Rabi, 2014 at college farm, college of agriculture, Rajendranagar, Hyderabad to realize the optimal dose of nitrogen and sulphur in safflower and to evaluate the effect of levels of nitrogen and sulphur on yield and quality parameters of safflower. The experiment was carried out with three nitrogen levels 0,40 and $60 \mathrm{~kg} \mathrm{~N} \mathrm{ha}^{-1}$ and three sulphur levels 0,25 and $45 \mathrm{~kg} \mathrm{~S}^{-1}$ were laid out in randomized block design with factorial concept and replicated thrice. With respect to nitrogen levels, Viz. number of capitula plant ${ }^{-1}$ (26.7), number of seeds capitulum ${ }^{-1}$ (24.0), weight of capitulum plant ${ }^{-1}$ (37.5 g), 100 seed weight (4.4 g), oil content (29.3\%) oil yield $\left(427 \mathrm{~kg} \mathrm{ha}^{-1}\right)$ and protein content $(16.0 \%)$ were recorded highest with $60 \mathrm{~kg} \mathrm{~N} \mathrm{ha}^{-1}$ and it was significantly superior than $40 \mathrm{~kg} \mathrm{~N} \mathrm{ha}^{-1}$ and $0 \mathrm{~kg} \mathrm{~N} \mathrm{ha}^{-1}$. Among sulphur levels, significantly highest yield parameters viz. number of capitula plant ${ }^{-1}$ (25.7), number of seeds capitulum ${ }^{-1}$ (22.6), weight of capitulum (35.1 $\left.\mathrm{g} \mathrm{plant}^{-1}\right), 100$ seed weight $(4.1 \mathrm{~g})$, oil content $(31.1 \%)$ oil yield $\left(448 \mathrm{~kg} \mathrm{ha}^{-1}\right)$ and protein content $(15.0 \%)$ were recorded with $45 \mathrm{~kg} \mathrm{~S} \mathrm{ha}^{-1}$ over $25 \mathrm{~kg} \mathrm{~S} \mathrm{ha}^{-1}$ and $0 \mathrm{~kg} \mathrm{~S} \mathrm{ha}^{-1}$.

\section{Introduction}

Safflower (Carthamus tinctorius L.) is an important annual industrial crop. The stem, leaves, seeds and flowers are used as vegetable and industrial oil, bird feed, forage plant, medicinal purpose and for its colourful petals used as food colouring, flavouring agent and preparing textile dyes (Dordas and Sioulos, 2008). Safflower oil preferred for its higher poly unsaturated fatty acid $(78 \%$ linoleic acid) which reduces blood cholesterol level (Belgin et al., 2007) also contains tocopherols, known to have antioxidant effect and high vitamin E content. For this reason, safflower oil is used in the diets of patients with cardiovascular disease, and bears great importance for its anti-cholesterol effect (Pongracz et al., 1995; Arslan et al., 2003). India is a major safflower growing country and contributes 60 per cent of the total world production. India ranks first in area and production of safflower grown across the world. In India, safflower is grown in an area of $1,78,400$ ha with a production of 1.453 lakh tonnes and productivity of $498 \mathrm{~kg} \mathrm{ha}^{-1}$ (Indiastat, 2012). But, the productivity of safflower is very low as the crop is cultivated under nutrient stress environment conditions. This necessitates rational application of these elements as they have become limiting factor for obtaining higher yields in safflower. 
Higher yields and quality of safflower oil can be realized only when all three major nutrients $(\mathrm{N}, \mathrm{P}$ and $\mathrm{K}$ ) and secondary nutrient (S) is supplied in sufficient quantity and in a balanced way. Apart from determining the response, identification of right dose is also very important to optimize production.

\section{Materials and Methods}

The field experiment was conducted at College farm, Professor Jyashankar Telangana State Agricultural University, Rajendranagar, Hyderabad during Rabi season 2014-15. The experimental soil was sandy loam in texture, slightly alkaline in reaction $\left(\mathrm{p}^{\mathrm{H}} 7.3\right)$. The fertility status of the experimental soil was low in organic carbon $(0.41 \%)$ and available nitrogen $(217.63 \mathrm{~kg}$ ha ${ }^{1}$ ), medium in available phosphorous (40.93 $\mathrm{kg} \mathrm{P}_{2} \mathrm{O}_{5} \mathrm{ha}^{-1}$ ) and high in available potassium $370.7 \mathrm{~kg} \mathrm{~K}_{2} \mathrm{O} \mathrm{\textrm {ha } ^ { - 1 }}$ ) and low in available sulphur (15.7 kg S ha-1). The experiment was laid out in a factorial randomized block design with three replications having nine treatments combinations of three levels of nitrogen $0 \mathrm{~kg} \mathrm{~N}$ ha $^{-1},: 40 \mathrm{~kg} \mathrm{~N}^{-1}$ and $60 \mathrm{~kg}$ $\mathrm{N} \mathrm{ha}^{-1}$ and three sulphur levels $0 \mathrm{~kg} \mathrm{~S} \mathrm{ha}^{-1}, 25$ $\mathrm{kg} \mathrm{S} \mathrm{ha}{ }^{-1}, 45 \mathrm{~kg} \mathrm{~S} \mathrm{ha}^{-1}$ ).

\section{Results and Discussion}

\section{Number of capitula plant ${ }^{-1}$}

The number of capitula plant ${ }^{-1}$ increased with increment of nitrogen dose because the application of $\mathrm{N}$ fertilizer. Application of 60 $\mathrm{kg} \mathrm{N} \mathrm{ha}{ }^{-1}$ recorded significantly more number of capitula plant ${ }^{-1}$ (26.7) over $40 \mathrm{~kg} \mathrm{~N} \mathrm{ha}^{-1}$ and $0 \mathrm{~kg} \mathrm{~N} \mathrm{ha}{ }^{-1}$. Other investigation also reported the positive effects on number of capitula plant ${ }^{-1}$ Singh and Singh (2013).

The highest number of capitula plant ${ }^{-1}(25.7)$ was recorded in the treatment receiving $45 \mathrm{~kg}$ $\mathrm{S} \mathrm{ha}{ }^{-1}$ and it was significantly superior over 25 $\mathrm{kg} \mathrm{S} \mathrm{ha}{ }^{-1}$ (24.4), and control (23.2). This might be because of better growth of plant due to availability of sulphur leading to increased number of capsules plant ${ }^{-1}$ as seed yield is directly related to the growth and yield attributes (Patil et al., 2014).

\section{Number of seeds capitulum ${ }^{-1}$}

Number of seeds capitulum ${ }^{-1}$ differed significantly among different levels of nitrogen. Application of adequate nitrogen produced large number of seeds capitulum ${ }^{-1}$ with improved plant vigour coupled with increased production and translocation of photosynthates have accommodated more number of seeds capitulum ${ }^{-1}$.

Application of $60 \mathrm{~kg} \mathrm{~N} \mathrm{ha}{ }^{-1}$ recorded statistically higher number of seeds capitulum $^{-1}$ (24.0) over $40 \mathrm{~kg} \mathrm{~N} \mathrm{ha}{ }^{-1}$ and control. Lowest number seeds capitulum ${ }^{-1}$ (19.6) was observed in control $\left(0 \mathrm{~kg} \mathrm{~N}^{-}\right.$ $\left.{ }^{1}\right)$. These results are in line with Reddi Ramu and Maheswara Reddy (2003), Sharma and Gupta, (1992).

Among the sulphur levels, application of 45 $\mathrm{kg} \mathrm{S} \mathrm{ha}{ }^{-1}$ (22.6) registered the highest number of seeds capitulum ${ }^{-1}$. It was significantly superior over $25 \mathrm{~kg} \mathrm{~S}^{-1}$ (21.9) and control (21.1). Application of sulphur increased the plant growth by increasing the assimilating surface area. The higher photosynthates assimilation helped in net export of carbon to sink and thus increased the number of seeds capitulum $^{-1}$ (Kapila Shekhawat and Shivay, 2008).

\section{Weight of capitulum (g plant ${ }^{-1}$ )}

Weight of capitulum plant $^{-1}$ was significantly influenced when the safflower crop was fertilized with $60 \mathrm{~kg} \mathrm{~N} \mathrm{ha}^{-1}$ compared to other levels of nitrogen. The weight of capitulum plant $^{-1}$ was significantly higher $(37.5 \mathrm{~g})$ with 
$60 \mathrm{~kg} \mathrm{~N} \mathrm{ha}^{-1}$ compared to $40 \mathrm{~kg} \mathrm{~N} \mathrm{ha}^{-1}(33.6$ $\mathrm{g})$ and control $(28.3 \mathrm{~g})$. The highest weight of capitulum plant $^{-1}(35.1 \mathrm{~g})$ was recorded in the treatment receiving $45 \mathrm{~kg} \mathrm{~S} \mathrm{ha}^{-1}$ and it was significantly superior over $25 \mathrm{~kg} \mathrm{Sha}^{-1}$ and 0 $\mathrm{kg} \mathrm{S} \mathrm{ha}{ }^{-1}$.

Higher weight of capitulum plant ${ }^{-1}$ might be due to higher yield components that are directly responsible for higher seed yield determined by physiological characters both during vegetative and reproductive phase of the crop (Ravi et al., 2010).

\section{0 seed weight}

100 -seed weight differed significantly among different levels of nitrogen and sulphur. Application of $60 \mathrm{~kg} \mathrm{~N} \mathrm{ha}{ }^{-1}$ recorded significantly highest 100 -seed weight $(4.4 \mathrm{~g})$ over $40 \mathrm{~kg} \mathrm{~N} \mathrm{ha}^{-1}(4.1 \mathrm{~g})$ and $0 \mathrm{~kg} \mathrm{~N} \mathrm{ha}$ $(3.3 \mathrm{~g})$. Test weight among different sulphur levels maximum was obtained $(4.1 \mathrm{~g})$ with highest sulphur level $\left(45 \mathrm{~kg} \mathrm{~S}^{-1}\right)$ and it reduced with decrease in the sulphur levels and it was significantly superior over $25 \mathrm{~kg} \mathrm{~S}$ $\mathrm{ha}^{-1}(3.9 \mathrm{~g})$ and the lowest test weight was recorded in control (3.7 g) (Table 1).

The increase in 100 seed weight with higher sulphur level may be due to the balanced system of nutrition and consequently producing healthy seeds (Mishra and Agrawal, 1994). These results are in conformity with the results of Ravi et al., (2010), Singh and Singh (2013), Dashora and Sharma (2006).

\section{Oil content (\%)}

Oil content differed non-significantly among different levels of nitrogen. But, among different levels of nitrogen, control $(0 \mathrm{~kg} \mathrm{~N}$ $\mathrm{ha}^{-1}$ ) recorded higher oil content $(30.2 \%)$ over 60 and $40 \mathrm{~kg} \mathrm{~N} \mathrm{ha}^{-1}$. Lowest oil content was observed in $60 \mathrm{~kg} \mathrm{~N} \mathrm{ha}^{-1}(29.3 \%)$.

Table.1 Yield attributes of safflower as influenced by nitrogen and sulphur levels

\begin{tabular}{|c|c|c|c|c|}
\hline Treatments & $\begin{array}{c}\text { No. of } \\
\text { Capitula } \\
\text { plant }^{-1}\end{array}$ & $\begin{array}{c}\text { No. of } \\
\text { Seeds } \\
\text { capitulam }\end{array}$ & \begin{tabular}{|c} 
Weight of \\
Capitula \\
plant $^{-1}(\mathrm{~g})$
\end{tabular} & $\begin{array}{l}100 \text { seed } \\
\text { Weight (g) }\end{array}$ \\
\hline \multicolumn{5}{|l|}{ Nitrogen levels } \\
\hline $\mathrm{N}_{0^{-}}-0 \mathrm{~kg} \mathrm{ha}^{-1}$ & 22.1 & 19.6 & 28.3 & 3.3 \\
\hline $\mathrm{N}_{1}-40 \mathrm{~kg} \mathrm{ha}^{-1}$ & 24.5 & 21.9 & 33.6 & 4.1 \\
\hline $\mathrm{N}_{2}-60 \mathrm{~kg} \mathrm{ha}^{-1}$ & 26.7 & 24.0 & 37.5 & 4.4 \\
\hline SEm \pm & 0.38 & 0.21 & 0.59 & 0.05 \\
\hline $\mathrm{CD}(\mathrm{P} \leq 0.05)$ & 1.15 & 0.64 & 1.78 & 0.15 \\
\hline \multicolumn{5}{|l|}{ Sulphur levels } \\
\hline $\mathrm{S}_{0}-0 \mathrm{~kg} \mathrm{ha}^{-1}$ & 23.2 & 21.1 & 31.2 & 3.7 \\
\hline $\mathrm{S}_{1}-25 \mathrm{~kg} \mathrm{ha}^{-1}$ & 24.4 & 21.9 & 33.0 & 3.9 \\
\hline $\mathrm{S}_{2}-45 \mathrm{~kg} \mathrm{ha}^{-1}$ & 25.7 & 22.6 & 35.1 & 4.1 \\
\hline SEm \pm & 0.38 & 0.21 & 0.59 & 0.05 \\
\hline $\mathrm{CD}(\mathrm{P} \leq 0.05)$ & 1.15 & 0.64 & 1.78 & 0.15 \\
\hline \multicolumn{5}{|l|}{ Interaction $(\mathbf{N} \times S)$} \\
\hline SEm \pm & 0.66 & 0.37 & 1.03 & 0.09 \\
\hline $\mathrm{CD}(\mathrm{P} \leq 0.05)$ & NS & NS & NS & NS \\
\hline
\end{tabular}


Table.2 Oil content, oil yield and protein content of safflower as Influenced by nitrogen and sulphur levels

\begin{tabular}{|c|c|c|c|}
\hline Treatments & $\begin{array}{c}\text { Oil content } \\
(\%)\end{array}$ & $\begin{array}{l}\text { Oil yield } \\
\left(\mathrm{kg} \mathrm{ha}^{-1}\right)\end{array}$ & $\begin{array}{c}\text { Protein } \\
\text { Content }(\%)\end{array}$ \\
\hline \multicolumn{4}{|c|}{ Nitrogen levels } \\
\hline $\mathrm{N}_{0}-0 \mathrm{~kg} \mathrm{ha}^{-1}$ & 30.2 & 348 & 11.5 \\
\hline $\mathrm{N}_{1}-40 \mathrm{~kg} \mathrm{ha}^{-1}$ & 29.4 & 391 & 13.9 \\
\hline $\mathrm{N}_{2}-60 \mathrm{~kg} \mathrm{ha}^{-1}$ & 29.3 & 427 & 16.0 \\
\hline $\mathrm{SEm} \pm$ & 0.26 & 10.06 & 0.36 \\
\hline $\mathrm{CD}(\mathrm{P} \leq 0.05)$ & NS & 30.15 & 1.06 \\
\hline \multicolumn{4}{|l|}{ Sulphur levels } \\
\hline $\mathrm{S}_{0^{-}}-0 \mathrm{~kg} \mathrm{ha}^{-1}$ & 28.1 & 306 & 12.6 \\
\hline $\mathrm{S}_{1}-25 \mathrm{~kg} \mathrm{ha}^{-1}$ & 29.8 & 389 & 13.8 \\
\hline $\mathrm{S}_{2}-45 \mathrm{~kg} \mathrm{ha}^{-1}$ & 31.1 & 448 & 15.0 \\
\hline $\mathrm{SEm} \pm$ & 0.26 & 10.06 & 0.36 \\
\hline $\mathrm{CD}(\mathrm{P} \leq 0.05)$ & 0.74 & 30.15 & 1.06 \\
\hline \multicolumn{4}{|c|}{ Interaction ( $\mathbf{N} \times \mathbf{S})$} \\
\hline $\mathrm{SEm} \pm$ & 0.45 & 17.42 & 0.62 \\
\hline $\mathrm{CD}(\mathrm{P} \leq 0.05)$ & NS & NS & NS \\
\hline
\end{tabular}

Oil content decreased with increase in nitrogen level from 0 to $60 \mathrm{~kg} \mathrm{~N} \mathrm{ha}{ }^{-1}$. Reduction in oil content in seed by higher $\mathrm{N}$ application might be due to higher degradation of carbohydrates in tricarboxylic acid (TCA) cycle to acetyl Co A. By reductive amination and transamination process more amino acids are formed rather than fatty acids. Crop fertilized with $60 \mathrm{~kg} \mathrm{~N}$ $\mathrm{ha}^{-1}$ resulted in comparatively greater accumulation of protein in seed, there by hindering a satisfactory availability of carbohydrates for polymerization into fatty acids and thus leading to lower content of oil in the seed (Zaman, 1988).

The treatment receiving $45 \mathrm{~kg} \mathrm{~S} \mathrm{ha}^{-1}$ resulted in the maximum oil content $(31.1 \%)$. This was significantly superior over $25 \mathrm{~kg} \mathrm{~S} \mathrm{ha}^{-1}$ $(29.8 \%)$ and $0 \mathrm{~kg} \mathrm{~S} \mathrm{ha}{ }^{-1}(28.1 \%)$. The increase in oil content with increase in sulphur might be due to the involvement of sulphur in electron- transport chain. The acetic thiolinase, a sulphur based enzyme in the presence of sulphur converts acetyl Co A to melonyl Co A rapidly resulting in higher oil content (Krishnamurthi and Mathan, 1996 and Nagavani et al., 2001).

\section{Oil yield $\left(\mathrm{kg} \mathrm{ha}^{-1}\right)$}

Oil yield differed significantly among different levels of nitrogen. Application of 60 $\mathrm{kg} \mathrm{N}$ ha $^{-1}$ recorded maximum oil yield (427 $\mathrm{kg} \mathrm{ha}^{-1}$ ) over lower levels of $40 \mathrm{~kg} \mathrm{~N} \mathrm{ha}^{-1}$ and $0 \mathrm{~kg} \mathrm{~N} \mathrm{ha}{ }^{-1}$. Lowest oil yield was obtained in control (348 kg ha-1).

Higher oil yield with increasing nitrogen was probably due to favourable effect of nitrogen on seed yield. Thus crop receiving adequate nitrogen recorded higher oil yield despite of lower seed oil content (Reddy et al., 1994).

Oil yield of safflower increased steeply with increasing application rates of sulphur and attained maximum oil yield at higher doses of sulphur. Oil yield was maximum with sulphur application upto $45 \mathrm{~kg} \mathrm{~S}^{-1}$ and decreased with lower levels. Oil yield of safflower 
ranged from $306 \mathrm{~kg} \mathrm{ha}^{-1}$ in control to $448 \mathrm{~kg}$ $\mathrm{ha}^{-1}$ at $45 \mathrm{~kg} \mathrm{Sha}^{-1}$.

Oil yield is a function of oil content and seed yield, both the attributes increased with increasing levels of sulphur resulting in a significant increase in oil yield (Santosh Kumar et al., 2009). Higher oil yield with higher dose of sulphur fertilization was due to higher seed yield.

Further, application of sulphur to plant enhanced the formation of acetyl co enzyme A, a precursor compound for the synthesis of long chain fatty acid resulting in increase in oil content which ultimately led to greater oil yield (Panda et al., 2000).

\section{Protein content (\%)}

Protein content differed significantly among the different levels of nitrogen. Application of $60 \mathrm{~kg} \mathrm{~N} \mathrm{ha}{ }^{-1}$ recorded significantly higher protein content $(16.0 \%)$ over lower levels of $40 \mathrm{~kg} \mathrm{~N} \mathrm{ha}^{-1}$ and $0 \mathrm{~kg} \mathrm{~N}^{-1}{ }^{-1}$. Control $(0 \mathrm{~kg} \mathrm{~N}$ $\mathrm{ha}^{-1}$ ) recorded significantly lower protein content $(11.5 \%)$. Nitrogen is the main nutrient involved in amino acid structure, therefore application of nitrogen can increase the value of seed protein. Zohra et al., (1985) reported that nitrogen had positive effects on seed protein content of safflower (Table).

Application of sulphur significantly increased the protein content in seeds. There was differential increase in protein content due to the application of higher levels of sulphur than lower levels. The treatment receiving 45 $\mathrm{kg} \mathrm{S} \mathrm{ha}{ }^{-1}$ resulted in the highest protein content $(15.0 \%)$ and it was significantly superior over $25 \mathrm{~kg} \mathrm{~S} \mathrm{ha}^{-1}(13.8 \%)$ and $0 \mathrm{~kg}$ $\mathrm{S} \mathrm{ha}{ }^{-1}(12.6 \%)$. Sulphur is a constituent of essential amino acids methionine, cystein and cystine. Sulphur also helps in conversion of these amino acids into high quality protein. Appropriate structure is essential for protein formation and sulphur provides di-sulphide (S-S) bonds for cross linkage of two polypeptide chains and thus helps in formation of proteins (Allaway and Thompson, 1966).

\section{References}

Allaway, F.J and Thompson, J.F. 1966. Sulphur in the nutrition of plants and animals. Soil Science. 101: 240-247.

Arslan B,Altuner F, Tuncturk M (2003). An investigation on yield and yield components of some safflower varieties which grown in Van. $5^{\text {th }}$ Field Crops Congress of Turkey, 1: 468-472.

Baviskar, P.K., Varsha, V.T., Jagdale, R.B., Sarika, V.S and Bhatia, N.H. 2005. Effect of levels of sulphur and its sources on S uptake, growth and yield of safflower. Journal of Soils and Crops. 15(2): 466-469.

Belgin, C., G. Bilal and K. Mustafa, 2007.Oil content and fatty acid composition of some safflower (Carthamus tinctorius L.) varieties sown in spring and winter. Inter.J. Nat. and Eng. Sci., 1(3): 11-15.

Bitarafan, Z., Shirani-Rad, A. H and Delkhosh, B. 2011. Nitrogen rates and sowing date effect on yield and oil content of spring safflower. International Journal of Science and Advanced Technology.1 (6): 25-30.

Dajue L, Mundel HH (1996). Safflower, Promoting the Conservation and Use of Underutilized and Neglected Crops. 7. Institute of Plant Genetics and Crop Plant Research, Gatersleben/International Plant Genetic Resources Institute, Rome, Italy. p. 85.

Dashora, P and Sharma, R.P. 2006. Effect of sowing date, irrigation and sulphur nutrition on yield attributes, yield and oil content of safflower. Crop Research. 31(1): 56-57.

Dordas, C and Sioulas, C. (2008). Safflower 
yield, chlorophyll content, photosynthesis, and water use efficiency response to nitrogen fertilization under rainfed conditions. Indian Crop Production. 27: 75-85.

Kapila Shekhawat and Shivay, Y.S. 2008. Effect of nitrogen sources, sulphur and boron levels on productivity, nutrient uptake and quality of sunflower (Helianthus annuus). Indian Journal of Agronomy. 53(2):129-134.

Karaca M, Guler M, Durutan N, Meyveci K, Avci M, Eyyuboglu H, Avcin A (1989). Effect of rotation systems on wheat yield and water use efficiency in dryland areas of anatolia. Papers submitted in 1989. Field Crops Central Research Institute. General Publications. No: 1990/1. Ankara, Turkey.

Karle, B.G., Malewarw, G.V and Ghonishkar, C.P. (1985). Sulphur nutrition in Maharashtra agriculture. A Review Proceedings of the National Seminar on Sulphur in Agriculture. October, 18-19. 55-68.

Katole, N.S and Meena, G. P. 1988. Effect of row spacing, nitrogen and irrigation on seed yield, oil content and water requirement of safflower. Indian Journal of Agronomy.33 (3): 339-341.

Kaya MD, Đpek A, Ozdemir A (2003). Effect of different soil salinity levels on germination and seedling growth of safflower (Carthamus tinctorius L.). Trend Agric. Forest. 27: 221-227.

Krishnamoorthy, S. K. 1989. Sulphur fertilization for yield and quality of crops. Proc. National Seminar on sulphur in agriculture held at UAS, Bangalore, pp. 22-25.

Krishnamurthi, V.V and Mathan, K.K. 1996. Influence of sulphur and magnesium on growth and yield of sunflower (Helianthus annus). Indian Journal of Agronomy. 4: 627-629.
Kubsad, V.S. and Mallapur, C.P. 2003. Effect of sulphur nutrition on productivity of safflower. Journal of Oilseeds Research. 20(1): 96-98.

Mishra, A., Dosh, P and Paikaray, R.K. 1995. Yield and nutrient uptake by winter sunflower as influenced by nitrogen and phosphorous. Indian Journal of Agronomy. 40(1): 137-138.

Mishra, A.K. and Agarwal, H.P. 1994. Effect of sulphur on growth, yield, protein and oil content of soybean. Journal of Oilseeds Research. 11: 99-102.

Nagavani, A.V., Sumathi, V., Chandrika, V and Muneendra Babu, A. 2001. Effect of nitrogen and sulphur on yield and oil content of sesame (Sesamum indicum L.)

Panda, P.K., Sounda, G and Tripathy, S.K. 2000. Effect of irrigation and sulphur on yield, nutrient uptake and quality of mustard. Journal of Oilseeds Research. 17(1):122-126.

Patel, P.T., Patel, G.G., Patel, G.A., Sonani, V.V and Patel, H.B. 2002. Effect of sources and levels of sulphur on seed and oil yield of safflower (carthamus tinctorius).

Patil, S.S., Choudhary, A.A., Goley, A.V and Rasal, S.J. 2014. Effect of phosphorus and sulphur on growth, yield and economics of linseed. Journal of Soils and Crops. 24(1): 159-164.

Pongracz G, Weiser H, Matzinger D (1995). Tocopherole, Antioxidation der Nat. Fat. Sci. Technol. 97: 90-104.

Ravi, S., Channal, H.T and Shailendra Kumar. 2010. Response of sulphur and micronutrients ( $\mathrm{Zn}$ and $\mathrm{Fe}$ ) on yield and available nutrients of safflower (Carthamus tinctorius L.). An Asian Journal of Soil Science. 5(2): 402-405.

Reddi Ramu, Y and Maheswara Reddy, P. 2003. Yield, quality and economics of sunflower as influenced by nitrogen and sulphur nutrition. Journal of Oilseeds 
Research. 20(1): 131-132.

Reddy, Ch. P., Lakshmi, G. S and Santharam, M.V. 1994. Effect of levels of nitrogen and azospirillum inoculation on oil, protein content and oil yield of safflower and on N, P, K uptake. Journal of Oilseeds Research. 11 (1): 34-39.

Santosh Kumar, Verma, S.K., Singh, T.K and Shyambeer Singh. 2009. Effect of nitrogen and sulphur on growth, yield and nutrient uptake by Indian mustard (Brassica juncea) under rainfed condition. Indian Journal of Agricultural Science. 81(2): 145-149.

Sharma, R.A and Gupta, R.K. 1992. Response of rainfed soybean (Glycine max L.) safflower (Carthamus tinctorius) sequence to nitrogen and sulphur fertilization in vertisols. Indian Journal of Agricultural Sciences. 62(8): 529534.

Sharma, U.K and Bansal, K.N. 1998. Influence of different levels and sources of sulphur on yield and nutrient uptake by safflower grow on alluvial soils. Crop Research. 16(3): 306-308.

Singh, R.K and Singh, A.K. 2013. Effect of nitrogen, phosphorus and sulphur fertilization on productivity, nutrientuse efficiency and economics of safflower (Carthamus tinctorius) under late-sown condition. Indian Journal of Agronomy. 58(4):583-586.

Singh, S. B., Chauhan, Y. S and Verma. 1992. Effect of row spacing and nitrogen level on yield of safflower (Carthamus tinctorius) in salt affected soils. Indian Journal of Agronomy. 37 (1): 90-92.

Singh, S.P., Bansal, K.N and Nepalia, V. 2001. Effect of nitrogen, its application time and sulphur on yield and quality of soybean (Glycine max). Indian Journal of Agronomy. 46(1): 141-144.

Tomar, R.S. 2012. Response of linseed (Linum usitatissium) to sources and doses of sulphur in alluvial soils of Madya Pradesh. Crop Research. 43(13): 39-41.

Venkatesh, M.S., Hebsur, N.S and Satyanarayana, T. 2002. Evaluation of sulphur carriers for safflower in vertisol of North Karnataka. Karnataka Journal of Agricultural Science. 15(2):284-287.

Verma, A.K., Shrivastava, G.K., Tripathi, V.K and Kolhe, S.S. 2012. Response of safflower (Carthamus tinctorius L.) to sulphur fertilization in alfisols of Chhattisgarh Plains. Journal of Oilseeds Research. 29 (Spl.issue):244-245.

Zaman, A. 1988. Effect of nitrogen and phosphorus on yield attributes, seed yield and oil content of irrigated safflower in laterite soil. Annals of Arid Zone. 27 (1): 37-40.

Zhora, A., Medekkar, $\mathrm{S}$ and Shaik Mohammad. 1985. Response of safflower to nitrogen and phosphorus. Indian Journal of Agronomy. 30 (1): 128-130.

\section{How to cite this article:}

Revanth Nathan, J.K., A. Madhavi Lata, B. Joseph and Madhavi, A. 2017. Influence of Nitrogen and Sulphur on Yield and Quality Parametres of Spineless Safflower under Irrigated Conditions. Int.J.Curr.Microbiol.App.Sci. 6(7): 600-606. doi: https://doi.org/10.20546/ijcmas.2017.607.073 